Research Article

\title{
Raffles's observations of the arts of visual culture in Java during his reign in 1811-1816
}

\author{
Iswahyudi \\ Yogyakarta State University
}

\begin{abstract}
Raffles introduced government directly in Java and tried to do various things that he considered useful for his government. It abolished the slave trade, forced labor and permanent surrender of cash crops, and gave farmers the freedom to choose their own crops to grow. Later he also introduced the land tenure system, which abolished the unpopular forced farming system established by the Dutch, in which crops were grown and handed over to the government. In addition, he ordered the restoration of the Borobudur temple and other temples, and allowed research related to these cultural buildings. During his reign, Raffles increased his knowledge of Javanese customs, history, beliefs, geography, and natural history and compiled information for a book which he would later publish. This has a very big influence when it is associated with the end of the British rule in Java, it has a direct and indirect impact on the development of information and appreciation of the reception of art and culture observers of the indigenous Javanese population from Europe.
\end{abstract}

Keywords: Raffles, Java, art, culture, landrente, picture plate

\section{Introduction.}

One of the historical studies that departs from a person's character is a writing that has not been done much in Indonesian history. Starting from this problem, by trying to reveal the role of Lieutenant Governor Thomas Stamford Raffles, who in this case was one of the figures who had played a role as a ruler in the Dutch East Indies region, especially in Java during the period known as the British transitional government in 1811 - 1816. Besides his role as head of government, Raffles is also known as someone who has great interest and concern for arts and culture, especially in Java, Sumatra and Kalimantan. This has a very big influence if it is associated with the end of the British rule in Java, it has a direct or indirect impact on the development of information and appreciation of the reception of art and culture observers from Europe who really pay special attention to the charm of this potential. in the Dutch East Indies.

In contrast to the VOC, the British East India Company (EIC) was not taken over by the state, but at the end of the eighteenth century was placed under state supervision in such a way that it actually formed a semigovernmental corporation. When Napoleon annexed the Netherlands to France in 1810, the British government felt that the EIC should eliminate the island of Java as a potential French threat to Britain's position in Asia.

The EIC is ruled overseas by a governor-general based in Calcutta. In preparing the expedition against Java, he involved a young official, Thomas Stamford Raffles, who knew Malay well and had many contacts in the archipelago. Raffles tried, among other things, to persuade the Palembang sultan and the Javanese princes to side with the British. The EIC sent an army of twelve thousand men to Java, which landed in August 1811. Daendels' envisioned fortifications failed. His successor had to surrender after six weeks, partly because the native army did not support him enough. Raffles was appointed lieutenant governor of the former Dutch colonies in the archipelago, with the exception of Maluku and the west coast of Sumatra. Raffles believed that he was a much better administrator than his Dutch predecessors, especially for the indigenous population. But in reality, many of his actions in the judiciary and administration are in line with those of Daendels (Burgers, 2011). 
Furthermore, Raffles acted no less radically against the native kings than Daendels. Because the sultan of Palembang had killed the Dutch in his area and then declared his independence, Raffles sent a punitive expedition there and appointed a new sultan. He placed the provinces of Banten and Tjirebon under direct rule, so that now only the princely lands of Central Java in Java remained outside the control of the regions that were directly controlled by Java. Raffles' most important innovation was the introduction of a land use tax to replace forced shipping and corvées. To justify the new system, the theory was based that all land in Java belonged to the kings. It is now owned by the government and will be allowed to collect this rent from the cultivators of the land. In accordance with its meaning in the English word for rent, the new levy is called 'land rent'. Depending on the fertility of the soil, this means a quarter to half of the crop, which must be paid for in money or rice. The introduction of the new system began at the end of 1813 (Burgers, 2011: 73).

What is now known about the life of Sir Thomas Raffles is largely based on nineteenth century books, namely Sophia Raffles' Memoir of the Life and Public Services of Sir Thomas Stamford Raffles and Demetrius Charles Boulger's Life of Sir Stamford Raffles. (Raffles, 1992; Boulger, 1973). These works are considered the most reliable biographical records because they are based on first-hand knowledge and factual documents. Both books describe a romantic view of Raffles' early life, his career in the East India Company, and his role as Lieutenant Governor in Java. As a result, the persona of Raffles that emerges from this biographical record is one of the great human reformers and conquerors (Mault, 2005: 11).

On December 31, 1799, the VOC was officially declared bankrupt and the entire VOC territory in Indonesia was taken over by the Dutch government, which later changed its name to the Dutch East Indies. Meanwhile, French troops under the rule of Napoleon Bonaparte were invading the Netherlands. In 1795 the Netherlands became Bataafse Republiek (Batavia Republic) and Napoleon's brother, Louis Bonaparte, was made king. Bonaparte appointed Herman Willem Daendels as Governor General of the Dutch East Indies. After his appointment, Daendels attempted to introduce reforms into his domain, which created hostility among Javanese aristocrats who had benefited from the old system. Fearing that the French would gain complete control over all Dutch possessions and thereby threaten British interests in the Far East, the British decided to attack Indonesia. In 1811 the British captured Batavia. A month later the French surrendered, left Indonesia and would then be ruled by the British East India Company.

In this situation Lord Minto, Governor General of the British East India Company in Calcutta, India, appointed Sir Thomas Stamford Raffles as Lieutenant Governor General of Java and his territory. As Lieutenant Governor-General of Java, Raffles, like Daendels, sought to institute reforms. Unlike his predecessors, however, Raffles' reforms were generally well received by the indigenous population. Raffles introduced partial self-government and sought to abolish the slave trade; he abolished forced labor and fixed quotas for cash crops; and he gave farmers free choice which crops to grow. He also introduced a land tenure system, which abolished the unpopular forced farming system established by the Dutch, in which crops were grown and handed over to the government. In addition, he ordered the restoration of Borobudur and other temples, and allowed research to be collected on these cultural buildings. During this period of reign, Raffles increased his knowledge of Javanese customs, history, beliefs, geography and natural history and compiled information for a book to be published at a later date (Mault, 2005: 8).

Raffles' reforms did not last long. At the start of the Napoleonic Wars, the British government agreed that Dutch colonial possessions would be returned to the Netherlands at the end of the war. Despite Raffles' objections, Dutch government was re-established in Indonesia in 1816. After the Dutch returned to power, Raffles' reforms were scrapped. The new government returned to a system of forced labor, production restrictions, and the slave trade. In 1816, Raffles returned to England and a year later his work "The History of Java" was published. It wasn't long before Raffles was knighted. He returned to Asia in 1818 to become Lieutenant Governor of Bengkulu in West Sumatra. During this time, the Netherlands and England once again became rivals in trade. Raffles believed that the British needed to act and from his position as Lieutenant Governor, Raffles established the settlement of Singapore. He felt that this could counter Dutch influence in the region (Quigley, 1996: 5-41).

\section{Western explorers' notes on various artistic and cultural potentials in the archipelago}


Orientalism in historical studies is actually not something new if it must be limited to a move from a certain nation that is in a certain place or if there is a transition of goals because there is a sense of interest from certain nations towards other nations. Various events that are recorded in historical events, if based on lexical terms which are interpreted as oriental, are only limited when the Eastern world has to be a certain target, for example for economic purposes, then begins to develop with an alibi of neutrality for cultural interests, is something that may be used not to become a discourse. According to Edward Said there is a compilation that the term orientalism in a transparent sense is related to Arthur James Balfour's speech before the British Lower House on June 13, 1919, namely we must consider the East because there was also the Oriental Renaissance (Said, 1994). Orientalism in a real sense cannot be said to be a historical process if it does not begin with the meaning of colonialism or a westernized model under the guise of a civilizing mission towards non-Western people. What happened to the widespread practice of modern colonialism, someone will surely mention when Adam Smith, a British philosopher who in 1776 with his book "The Wealth of Nations" strongly supported the rise of the Industrial Revolution in England and immediately had to practice serious and organized colonialism.

Works on Indonesia written by Westerners began to appear in Europe in the early 15th century. Most of the stories were written by explorers whose main goal was to uncover a world unknown to Europeans. Stories describing the journeys of explorers and the people and lands they encountered. In 1505 Ludovico di Varthema traveled to the Maluku islands in Indonesia. Upon his return to Europe in 1510, he published his Itinerario, which inspired further notes by other explorers and adventurers. In 1596, Jan Huygen van Linschoten followed the publication of his Itinerario. Linschoten was a Dutch adventurer who was on a Portuguese ship to the Indies. The itinerary is the first travel record to describe the Portuguese Indies region, which was previously still seen by the Western world as a mysterious world (Wall, 1930: 4). Included in his writings are several engraved lines depicting Javanese people. The addition of pictorial plates depicting Indonesia's topography and ethnography will become a recurring trend in Western travel records. Among the best seventeenth century tablets on Indonesia is the work of Joan Nieuhof published in Amsterdam in 1682. The plates became popular and inspired many artists to create and reinterpret Nieuhof's drawings (Norman, 1857: 46-7).

The first book to use a combination of text and illustrations was François Valentijn's "Oud en Nieuw OostIndiën" published in Amsterdam in 1724. This work is considered the main source for a description of Indonesia which includes geography, society, topography, and natural history. Indonesia, as well as records of the conquest of the island of Java by the Dutch. This work later inspired many writers to combine text models with illustrations. Explorers' encounters with unknown peoples, customs, geography, animals, and plants are often documented and cataloged through a combination of text and illustrations. This idea of cataloging emerged in the eighteenth century and remained a popular form of unknown documentation and categorization throughout the nineteenth century. During the eighteenth century, the most prominent catalog in the field of natural history was that of Georgius Everhardus Rumphius. He is an expert on flora, fauna and geology of the island of Ambon. In 1705 he wrote "D'Amboinsche Rariteitkamer" which contains descriptions and sketches of organisms found in the sea, such as crabs, shrimp, sea urchins, and mussels, as well as rare minerals and fossils taken from animals and plants (Sprierings, 2013: 11). -12).

Writers from countries other than the Netherlands began to explore the archipelago. During the first quarter of the nineteenth century, the most spectacular Indonesian tablets were published in London. John Barrow's "A Voyage to Cochinchina", for example, features the first aquatint in Java. A quarter of Barrow's book describes his travels to Vietnam and the remainder describes his explorations of Madeira, the Canary Islands, Rio de Janeiro, Cape, Batavia, and Java. Among the three colored aquatint plates, one depicts an encounter between a native Javanese and a shark off the west coast of Java. The slab is accompanied by a narration that describes Barrow's narrow escape with a "fierce shark" and a Javanese native whose boat was nearly capsized by a ten-foot-eight-inch long shark. Barrow described how the shark was speared by the Javanese, lifted onto Barrow's boat and split open to reveal its contents. However, the image accompanying this description is not very concerned with an accurate depiction of the indigenous population of Java. Its sole purpose is to enhance the exotic and adventurous themes that Barrow wishes to express in his story (Sprierings, 2013: 13). 
Five years later an English orientalist named William Marsden presented eight large colored aquatints and several colorless plates in the third edition of his written notes entitled "The History of Sumatra" (Van Niel, 2005: 230-1, 243-285). The majority of these plates were completed by Joseph C. Stadler and based on drawings of Samuel Andrews, depict natural history, flora and fauna. Two plates depict weapons, two plates depict landscapes, and two plates depict house features with small figures (Haan, 1901: 219). The Stadler slab depicting a British settlement at Fort Marlborough is considered to be of greatest historical importance, but on the same slab on the obverse depicting a Bengkulu native Malay made by engraver Anthony Cardon. Unlike previous artists who depicted indigenous Indonesians, Cardon carefully studied the features of the Malay language and sought to capture representations accurately. Although the image appears rather romantic with the influence of elongated features, it became an important work in increasing European interest in ethnographic studies.

In 1810, the French writer C.F. Tombe wrote his work entitled "Voyage aux Indes Orientales" which featured four ethnographic plates with Malay, Javanese and Balinese nuances. These plates were completed by engraver V. Adam based on Tombe's own drawings. On these plates it appears that the first three plates lack the background, namely "Malais de Java avec la coiffure ordinaire", "Malais de Java avec la coiffure de ceux de Bantam" and "Ronguine de Java dansant", it seems that Tombe only wants to focus on natives and their costumes only. The figures stand on a small plot of land and pose in a way that represents a moment in the daily life of a Javanese native. Apart from showing some small coconut trees, the environment of the characters has nothing to do with the nuances of the Eastern world. The amount of oriental imagery and exoticism in these plates is minimal and very little embellishment is included. On the other hand, the oriental image on the fourth slab, namely "Malais de l'Isle de Baly," is exaggerated. The Balinese figure is made to look like a savage Easterner. He is also a central figure, but he is much larger than those in the other plates. It's like being surrounded by forest. In addition to his large stature, the figure appeared very hairy and muscular. The costumes and clothes are kept to a minimum. While the previous plates document Javanese clothing, the Balinese figure only wears a plain colored loincloth (Mault, 2005: 36).

Tombe's concentration on the indigenous Javanese population at the expense of their environment greatly influenced Raffles' "The History of Java". After serving as Lieutenant Governor of Java, Raffles returned to London and began preparations for the publication of The History of Java. His plans for the project began in 1811. To this end, he has collected many documents of Javanese culture, including ancient and modern musical instruments, models, books, drawings, fabrics, and carvings on wood and metal, as well as natural history. specimens such as plants, animal skeletons and skins. The extraordinary collection was then brought to London and served as source material for Raffles. The History of Java was written in one year and a total of 900 copies were published in May 1817 by the booksellers East India Company, Black, Parbury \& Allen, and John Murray. What made The History of Java extraordinary at the time was the inclusion of sixty-six slabs in it. Ten of these plates, completed by artist William Daniell as representing Raffles' broad interest in ethnography (Mault, 2005: 37) A total of nine of the aquatint colored plates depict Javanese costumes, and one depicts Papuans helping Raffles in Java and even accompanying him. to England in 1816.

Raffles, apart from taking the pictures in Tombe's works, also took inspiration from other works such as Valentijn's "Oud en Nieuw Oost-Indiën", Barrow's "A Voyage to Cochinchina", and Rumphius' "Herbarium Amboinense". In The History of Java, Raffles cites many of these works, Raffles choosing to catalog various aspects of Javanese culture and history, and to document his work through his meetings with indigenous people. The extent to which earlier travel records shaped Raffles' work is most evident when comparing The History of Java with William Marsden's The History of Sumatra. Despite the similarity of titles, both the works of Raffles and Marsden, according to Bastin and Brommer, are considered the most serious and reliable studies of these areas (Bastin and Brommer, 1979: 6). Marsden's records describe the government, laws, customs, and manners of the natives. Raffles' notes on Java also cover the same topic. Each chooses to document natural history and ancient history, including images and descriptions of geographical features, natural phenomena, wildlife, flora, and objects of trade. Both works also contain information about indigenous peoples and their culture, including behavioral differences among other indigenous peoples, marriage customs, laws, food, crafts, and maps. 
What distinguishes these books from other books on Indonesia prior to 1817 is Raffles' interest in ethnography and the depth of his concentration on the Javanese and their costumes. Although previous publications established the basis for what is known about Java and Indonesia, they neglected to fully investigate Indonesia from an ethnographic perspective. It is clear that Raffles' style used to write his work was not original, but no previous book has combined text and imagery on history, culture, and antiquities devoted to a single Javanese subject. Thus, Raffles' book stands apart from other books published exclusively in Java at that time (Mault, 2005: 27-31).

Due to Raffles' innovations in depicting various aspects of the daily life of Javanese people, especially the pictorial depictions of Javanese costumes, interest in Indonesian works related to ethnographic subjects grew after 1817. Writers and artists also had a greater interest in the study and depiction of the Indonesian population. In 1824, the French writer J.F. Marchal wrote a book entitled "Description Géographique, Historique et Commerciale de Java et des Autres Iles de L'Archipel Indien", which contains the first color lithographs depicting Indonesian costumes and topography. This work combines Raffles' The History of Java and John Crawfurd's "History of the Indian Archipelago". His work contains forty-five plates, ten of which are colored lithographs and thirty-five colorless lithographs. The plates depicting antiques and Javanese costumes are taken directly from the Raffles plates; some, however, are printed upside down. In fact, Marchal's work is not the only work that traces the plates found in Raffles' work (Bastin and Brommer, 1979:9) Among the many works that reverse or reinterpret Raffles' plates are those of Frederic Shoberl of 1824, JBJ van Doren in 1851, E. Spanier in 1857 and many others.

A series of works published between 1830-1847 by François Vincent Henri Antoine de Stuers focused exclusively on the ethnography of Indonesians so that each plate showing the indigenous population only depicts a half-length figure up close. Although the facial features of the characters stand out, minimal attention is paid to their costumes. The figure is a prominent Indonesian leader, while the figure of Raffles is a non-specific representation of the Javanese. The characters in de Stuers' tale may not be so important in the depiction of their costumes; they deserve attention for their depiction of physiognomical defects. The first books devoted to explaining the Indonesian population are the book "Nederlandsch Oost-Indische Typen" by Auguste Van Pers and the book "Java, Tooneelen uit het Leven" by Ernest Hardouin. These stories describe the various ethnic groups and social arrangements in Java, both in traditional settings and in colonial urban settings (Bastin and Brommer, 1979:30). Among all the records of the Indonesian population, the plates in the works of Van Pers and Hardouin are said to be the most revealing about the life, customs, culture, and clothing of the Javanese in the nineteenth century. Although not as well known or as widely reproduced as the aquatints of Raffles' "The History of Java," their imagery provides a more comprehensive view of the inhabitants of the area. The Hardouin Plate depicts not only the indigenous people of Java, but also Muslim, Chinese, and African immigrants living in Java. Much attention is paid to the costumes of the characters represented, but they are depicted around them, not on an unspecified plot of land. As a result, the focus on these plates appears to be on the figures in their original setting, whereas the Raffles plates seem to focus exclusively on the figures and costumes of the natives. The setting itself doesn't overshadow the figure. Instead it helps to reveal aspects of the daily lives of residents and their interactions with each other as well as with strangers. As a result, Van Pers and Hardouin's images show the moment being immortalized. Their figures are not just on display, but seem to describe what life in Java was like in the nineteenth century.

\section{Positive image of Raffles as a scientist and cultural observer and his role in the association "Het Bataviaasch Genootschap van Kunsten en Wetenschappen"}

Historians mainly examine the economic steps taken by Raffles, in which the implementation of the land tax system took the most important place. Art historians examined the large number of drawings and objects that Raffles brought from the Dutch East Indies to London. Scientists still use "The History of Java" as an important source of knowledge about Java because they believe that this book marks the beginning of European interest in Javanese culture. Bastin said that it would be difficult to deny the importance of Raffles' book and that it would remain one of the most important and influential books on Indonesia ever published (Bastin, 2004: 56-61). 
One of the scientists who has written a lot about Raffles, both scientific and more popular works is Nigel Barley. This anthropologist has spent nearly twenty years working at the British Museum as curator of the "Raffles collection." He had a very strong and positive opinion of Raffles. Some of his statements say that Raffles was an unconventional man and that his ideas were more important than many other things. Although a colonialist, he is remembered as a reformer and pioneer of social justice and Raffles actually liked Eastern people and treated them with respect. The Javanese in Raffles' eyes are civilized people (Barley (ed.), 1999: 13).

John Bastin has a special place among scientists because he covered the entire spectrum of research on Raffles. He has published a number of books on Raffles' reforms, but has also worked in the field of art history, usually in collaboration with art historians. Bastin's studies have a solid scientific basis and he demonstrates indisputably that the reorganization of Raffles did not produce the desired results for the British treasury nor the liberation of the Javanese people. He also proved that Raffles distorted the facts about this in "The History of Java" (Spierings, 2013: 12). However, the tone is mostly positive and underscores the humanity of the Raffles government. He defended Raffles in cases that paint a more negative image. Bastin believes that many of the reforms carried out by Raffles were driven by sincere humanitarian motives. Raffles was not a pioneer of the modern indigenous administrative system in Java, but his important contribution to the development of British and Dutch colonial politics was that he based his government policies on humanitarian principles. Raffles did this through a benevolent policy of paternalism or autocracy (Bastin, 1957: XI-XII, 141-2).

In recent decades, many British publications from the early 19th century have been reprinted with prefaces or edited by Bastin. As a result, his opinion about Raffles often comes to the fore. He seems to have somewhat of a monopoly on research on Raffles and his reign in the Dutch East Indies. Many art historians rely on Bastin's publications as an introduction to their own research. For example, in a book written to commemorate 50 years of Indonesia, this book aims to show the longstanding relationship between Britain and Indonesia, it is stated that the Raffles collection is that everything is viewed by Raffles holistically and then raises the radical view that to understand and govern The island of Java properly, first of all, must be studied from every aspect of its environment and society as well as its culture, religion, history, language, literature, and culture (Gallop, 1995: 14). There are also some Dutch writers who more or less support the positive image of Raffles such as Van der Wall's way of saying that Raffles did a lot of good, increased income, reformed many violations since the VOC era, reorganized the administration of justice and the police, abolished the slave trade, collected important statistics. , and gave new life to Arts and Literature by reviving the dead Batavian Arts and Sciences Association (Wall, 1930: 4).

How much more is known about the period of Raffles' leadership at the Batavian Arts and Sciences Association (Het Bataviaasch Genootschap van Kunsten en Wetenschappen) from 1781 to 1826 . At first glance the material shows that he gave his own publicity. After many years, Discourse came out again, containing his speeches, which basically articulated the program of society. As such, he is a community strategist. Raffles continued to support Horsfield and ensured that his work was published: half of volume 7 and more than half of volume 8 of the Treatises belonged to Horsfield. Other Raffles supporters: Colin Mackenzie, John Leyden and John Crawfurd took care of the rest. The contribution of the Dutch members was minimal. Raffles also provides coverage through the Gazette. In addition, he helped the community with a new building in the vicinity of Societeit De Harmonie. His extensive collection and bookmarks of his work and the work of others in "The History of Java" (1817) completes the rest. As a result, Raffles was able to go down in history as the person who breathed new life into the Batavian Arts and Sciences Association and he became the second important figure in the history of society after Radermacher. Therefore, the period 18111816 deserves further exposure. However, it is also true for this period that the archive contains little or nothing. Some of the material appears to have gone to London with Raffles.

Raffles soon realized the existence of the association and the need to pay attention to science. In a letter to William Marsden, author of History of Sumatra, dated October 5, 1811, he wrote: 'Lord Minto is here now and we are thinking of advancing the Batavian Asiatic Society as soon as circumstances permit' (Wurtzburg 1984: 181). This passage is not entirely clear: are Minto and his deputy governor Raffles considering 
establishing the Batavian branch of the Asian Calcutta Society or does the letter refer to the need to promote the Batavian Association? Incidentally, the first new member of the association during this period was not Raffles himself but the Scottish engineer officer, Lieutenant Colonel Colin Mackenzie (1754-1821). He has worked in India as a surveyor and cartographer and has built archaeological-historical collections there. In the expedition to Java he appeared to be the right fit precisely because of his cartographic skills. Immediately after the takeover, he was tasked with creating an inventory of maps and archives in Batavia, as well as on the North coast, during a period during which the new government was collecting data on the colony's territory. Meanwhile, he also built his own collection, which is now housed as the Mackenzie Collection at the Oriental and India Collections of the British Library, where some of Raffles' papers are also kept (Groot, 2009).

It is clear that Mackenzie's election to membership at the council meeting on September 28, 1812, was related to his official duty: collecting data from the archives. He may have seen the libraries and collections of the Association, or what remains of them, before embarking on a nine-month journey across Java in November 1811. If not, then on his return to Batavia he wanted to compare his findings with those of the community. Upon his return in August 1812 he became known as a researcher and collector. He was in Batavia in September, as was Horsfield, and the association took advantage of him by tying the two men together. The Java Government Gazette considers elections to the military worthy of extensive reporting, which is the same as reporting on community activity again. Mention is also made of the large collection that Mackenzie collected on his travels. It is not stated that the manuscripts had been retrieved from the Kraton library in Djokjakarta several months earlier after the palace was looted: 'he had obtained various valuable and curious information and made a large collection of antiques, manuscripts and inscriptions (Groot, 2009:168-169) .

Mackenzie will report to its chief executive, Lord Minto of Calcutta, based on the data collected. His extensive diaries during his stay in Java, coupled with his official reports and collections, show that he collected systematically and extensively. His work on the committee to design a new land tax system, which required the measurement of the entire agricultural area, also required a systematic approach. Mackenzie, as it were, was a pioneer in the association of Rafles. The latter would make contact a month later, October 23, 1812: he invited all the remaining members in Batavia, thirty in number, to a dinner at which time Van Sevenhoven, at the request of the council, gave an account of history and purpose. from society. Thomas Horsfield had given several interesting natural history presentations at the members' meeting the previous week, on October 14, 1812. 26 His collection of natural history specimens will be sent to the East India Company museum in London (Java).

In September 1812 society was in the news again. The newspaper cautiously stated that community activities that were suspended a few years ago are likely to resume. Over dinner, in response to the historical outline of Van Sevenhoven's society, the lieutenant governor had presented himself as a defender of his interests by removing any obstacles that previously envious policies might have thrown in the path of liberal inquiry, by providing a more generous one. their meeting place, and facilitate the publication of their transactions by the Government Press (Java State Gazette 31-10-1812:2). An amendment to the Articles of Association was proposed, under which a committee would work.

New meeting rooms and access to government printing houses became important points for the community. Daendels has begun to move the seat of government to Weltevreden making the old Radermacher community home on the Grote Rivier an eccentric place. Daendels has left the unhealthy coastal path for a healthier South. People have experienced the consequences of living and working in the old city for years. Valuable board members died on the assembly line, membership files had to be constantly replenished. Therefore, Raffles' commitment is important in more ways than one: not only a better and new space, but also located in a healthier environment. During those months, didn't anyone think about the possibility of housing the Horsfield collection in Batavia and expanding the community museum? Mackenzie worked for Lord Minto, so he raised money for the British Government. He carries his 'own' (personal) collection as a matter of course. Horsfield, however, had begun his work in the service of the Batavian government, being appointed as him in 1802. It seems that Raffles had concluded that these collections would become British 
possessions. Incidentally, both in the newspaper reports and in Raffles himself programmed speeches meant silence on the part of the association on the part of the community. Would it be better left to the British? The paper also makes no mention of the formal role Raffles assumed in October 1812. He certainly established himself as a patron, but oddly enough, formal patronage was not mentioned in the newspapers.

It was not until February 1813 that Raffles became chairman, at which point it was decided at his suggestion to offer Lord Minto patronage. It is said that Raffles first took the position of open protector - which must have been in October 1812 - after which the public then offered this place to Lord Minto. After the failed patronage of Prince William V, the place was occupied for the first time, by the way, completely against the spirit of the 1800s. There was no room for patrons in the newly founded society at that time. Meetings were held regularly from September 1812. Reports were published in the Java Government Gazette magazine. Raffles' membership, however, did not appear in the newspapers. His name was at the top of the list of members in the archives at the meeting of February 15, 1813, the day seventeen others were made members. Sixteen others would follow by the end of the year bringing to a total of 34 new members in one year. Raffles himself later became chairman, while the association's council did not have a permanent chairman in previous years because it was democratically formed in 1800 .

In 1812 still rotated under B.F.W. Baron von Lutzow, former army commander, J. Paschen, Van Sevenhoven, former secretary of government and H.W. Muntinghe, president of the Council of Justice and extraordinary council during the British conquest. Muntinghe is the only one on the board to continue to hold senior positions in government and has remained with Ross on the core community council under Raffles. From 1813 the British signature of the membership was much stronger. H. Muntinghe became Vice President, while Ross and Daniel Ainslie became Secretary. Announcements about association activities in the Java Government Gazette appear in two languages: Dutch signed by Ross and English by Ainslie. Mackenzie sat on the editorial committee for the Treatise, and on the museum committee the secretary of government Ch. assy. Raffles did not completely alienate the old council. Von Lutzow and Van Sevenhoven were given places on the editorial board, which is called a committee on paper. Jeremias Schill and Ross were the only members of the new board of 1813 to escape the amendments of 1800 (Groot, 2009).

With Muntinghe as community leader alongside Raffles, the 'simple' layout desired by the 1800 generation was not maintained. Moreover, with the governor and members of both Councils at the helm, society soon became dependent again on the government. The government then did everything it could to ensure that dependence. The use of government printing presses and the prospect of new community houses made people feel that they could not operate independently. British representation on both committees, for publications and museums, means the UK is in control of society well. In November 1812, the first public assembly was held without ceremony at Muntinghe's house. On the anniversary of the community on April 24, 1813, a general meeting was held with a ceremony: at the Government Building and chaired by the Lieutenant Governor of Java. The 1800's program changes, simple furnishings, few luxuries, no general assembly, have been cancelled. We should think about this change for a moment. While in the new democratic draft of 1800 it was assumed in the first article that the association would be composed of the most capable and suitable citizens of this Capital, without consideration of status or rank', in 1813 this principle of French equality was abolished and it was imperative that the association be continues to be under the special protection of the British Government. That 'protection' didn't disappear in 1800, but it's definitely second to none.

So many of the enlightened minds of the 1800 s were interested in breaking with the past that they turned the goal of society to Article 8, where they first wanted to establish that government held all power, a government that would equip itself with choice. By relinquishing the dues, the 1800 reformers hope to open society to all those who were excluded in the past because of their number, eleven riksdalers a year. All this was changed under the supervision of Raffles: in the new formation of 1813 even five articles were devoted to the members. In 1813 the 'desire to expand Science' was the basis of the desired membership, but this was preceded by the requirement of 'known goodness', which introduced a new voting element or rather: one resembling despised ranks and positions from before 1795 . 
The membership fee and entry fee are set at ten Spanish coins each. The most striking difference is therefore clear: in 1800 the society wanted to establish itself independently, in 1813 it placed itself under the protection of the British government. In 1800, the association saw the board as the core of the organization and lacked respect for members, even abolishing the general meeting of members. With that he throws the baby out with bath water, because what is society without 'enjoyment'? And what is the role of the members if they can't make themselves heard at least once a year? The people of 1813 returned the members to their honor, with it a general meeting of the members, while the administrative structure was very precisely bound to the provisions. But the 1813 revision was a restoration: Governor General Minto as protector and Lieutenant Governor Raffles as chairman provided oversight from above; people lose their independence. Incidentally, the public, or at least Raffles, are aware of the 'back' to the 1778 setting.

What the reviewers of 1813 did not change was the outline of the goal, as set out in a separate article: they pursued, according to the formulation of Volume 7 of the Treatise, the common good in narrowly defined areas: explanation and expansion of natural history, language, antiquities, the manners and customs of the people of India and other special matters of these countries concerning the special zoning by the local relations of the special purpose of the Union, which also includes the promotion of agriculture and other matters relating to the prosperity of settlements shall not be forgotten (VBG 7, 1814:ix). Added to the 1800 formulation is a language study element. A restriction was made with respect to the original purpose of 1778. The encyclopedic "all arts and sciences" later came into effect and the restrictions on "this settlement" only applied to agriculture, commerce and special affluence. The unspecified arts and sciences are now contained.

For a closer look at the activities of the 1812-1815 meetings, see two of Chairman Raffles' speeches on April 24, 1813 and September 11, 1815. A separate program, as printed five times in the period 1778 - 1792, did not appear. In the first speech, Raffles showed himself as a diplomat by, as the new chairman of a Dutch organization, paying sufficient attention to history and at the same time placing a number of important members in the spotlight: Radermacher, Ross, Muntinghe, Engelhard, Couperus and Van Naerssen. . Two of them also sit on its own Council. Summarizing the contents of volume 7 of Verhandelingen, he once again commends foreigners, mentioning areas of activity that also deserve future attention such as natural history (Horsfield), archeology (Mackenzie on Prambanan) and ethnology (Leyden on Borneo). Raffles does not mention the two Dutch contributions in section 7, namely in the fields of medicine (Terne) and ethnology (Van Rijck), but these are twenty years old and were actually reprinted in 1814.

He then explicitly mentions the following as points of interest and areas of research namely language studies, particularly Javanese language as a gateway to the early history of the island, as well as Javanese thought and customs. A plan for a language studies institute is being considered. The idea of a targeted study of Javanese was born under Janssens, probably initiated by J. Chr. Baud, who continued to serve the government under Raffles. The second is research outside Java (eg Horsfield's research in Bangka). Then the last is research on customary law and institutions. Raffles eventually concretized a number of desiderata, citing the Asiatic Society of Calcutta as an example, which extended his research throughout Asia. He advised the Batavian association to confine itself mainly to areas closer to Java. He named as the research area: Bali, Kalimantan, Sulawesi, Halmaheira, New Guinea, the northern islands near the Philippines and Japan. By doing so, he showed that the Batavian Association should not hinder his colleagues in Calcutta.

Raffles' program didn't really work, but he did point out which areas needed attention. Two aspects are very important: language studies and research into areas that are still little known. The speech did not discuss how language research or ethnological-geographical research should be approached. That Raffles did not give up his ideas is shown by the fact that in 1823 he founded the Singapore Institute in Singapore for the study of Southeast Asian languages and cultures. In a speech on September 11, 1815, the fourth anniversary of the British takeover, Raffles also did not elaborate on a detailed program, but he did provide an extensive account of research carried out by others, without always stating explicitly whether the results of the research were to be published by the association. After a lengthy tribute to Lord Minto's late patron, the following are discussed in succession: Horsfield's report on his research in Bangka (to be published in London), Borneo and Celebes (without mentioning who the sometimes highly detailed research data came 
from), Java (among others reported are temple measurements by Captain GP Baker and language research by Reverend Th. Trowt), Bali, Javanese history and finally some statements about Japan (based on statements from Ainslie).

Verhandelingen provides an interesting setting, in which Raffles has included international literature on the subject (W. von Humboldt, W. Jones, J. Banks, E. Kaempfer) as well as recent discoveries and descriptions comparing one to another. Language research is discussed in several places. It remains a core research task in the archipelago. In addition, reporting shows that detailed research has been carried out in the past and Raffles was able to take accurate records. If no program is formulated in the detailed objectives and research projects, then we can read from this speech about what the Union should be. Raffles formulated his second report when he knew that his departure from Java was certain and also knew that he would not be the one to make the transfer to the Netherlands. He would hand over his office to Fendall and return to London. But in the September 1815 speech there was no immediate conclusion, much less farewell. The fact that his speech only emerged after his departure made it both a farewell address and a program for the future. Raffles explicitly mentions the results of research that will be published in Verhandelingen in several places: on the Kawi inscription found in East Java, the Cheribon manuscript and inscription described on copper plates, on the nature of the Javanese script, and on the Tengger prayer formulas. However, in the Discourse, this promised draft does not appear. Shall we assume that these essays are part of the material which Raffles brought to London in 1816 for volume 9 of Verhandelingen, as announced in the preface to section 8 (Bastin, 2004).

In 1816 those who were left were still waiting for this 9th volume to be printed in London. In 1823, when volume 9 was finally published in Batavia, there were only bitter words for Raffles' unfulfilled promises. 32 We are delighted to be able to substitute these ['tidy building materials' from the new volume 9] for the materials mentioned in the Introduction to Volume VIII of this Treatise. Here too, the lack of the Society's archives during those years is countered, for the board meeting report must have contained some information about this plan to print section 9 in London. The pieces that were taken and not returned form an interesting mystery. It is known that Raffles returned to London with a cargo: thirty tons in two hundred large boxes 34 packed, too much to list, but also a lot of written material which he would use for his History of Java. There is some suspicion in the appendix to this work (behind section 2), which contains several interesting texts: an extensive glossary in appendices E and F, treatises on Sulawesi and Bali, and a translation of the Kawi inscription. Raffles had spoken in his September 1815 speech about this 'extensive vocabulary', as well as about the Kawi inscription to be published, while in the same speech there was a section devoted to Bali and Sulawesi. Thus, part of 'London volume 9' seems to have ended in Raffles' important work on Java. But the 1823 councilors, who knew Raffles' History and who seemed to remember it very well, pointed no further than to the man and not to the appendix in the work, where they could find evidence of Raffles' behavior. The councilors in 1823 did not mention that Raffles used a copy of the Treatise in his work on Java. The renowned historian of the Javanese English period and the expert on Raffles John Bastin knew nothing about Volume 9 of Verhandelingen, which was supposed to be printed in London. However, he refers to the Malayan Miscellanies (1820-1821), two of which were published by the Sumatran Mission Press in Benkoelen publishing the Indonesianica bundle, published shortly after Raffles took power in Bengkulu (Bastin, 2004).

\section{Conclusion}

A turning point in the history of Indonesia is associated in his historiography with Raffles, who stated in his writings that his main aim was to elevate the status of the Javanese population. This humanitarian goal is often contrasted with the statement by Herman Muntinghe, a Dutch official who sits on the British Council, "that every colony exists or must exist for the benefit of the mother country". Raffles is seen as the person who liberated the Javanese people from the despotic regime of the Javanese regents and the Dutch government. Some British scholars teach that Raffles was "a benefactor of humanity through the kingdom". Raffles has also amassed a large collection of Javanese objects, manuscripts, naturalia, and drawings. The British are proud of the collection, which is now in London. 
Raffles' figure seems unique; he gained a reputation as a modern reformer with an interest in state traditions, a scientist-statesman. Raffles himself spread this image, followed by his widow Sophia Raffles. In the late 19th century, Raffles was 'rediscovered' and the first biographies of his life appeared. There followed many others in the 20th century. The most recent biography is from 2012 by Victoria Glendinning. There is also a group of scientists who are concerned with Raffles such as historians, researchers, anthropologists and art historians who mainly study the Raffles collection and criticize Raffles' reforms. John Bastin was an expert on Raffles and British rule in Java. Since the 19th century, objections have also been heard from writers who believed that Raffles' status was unjustified. This raises the question of whether Raffles' positive image is consistent with his actions or whether there are other aspects that explain his reputation.

There are also some Dutch writers who more or less support the positive image of Raffles such as Van der Wall's way of saying that Raffles did a lot of good, increased income, reformed many violations since the VOC era, reorganized the administration of justice and the police, abolished the slave trade, collected important statistics. , and gave new life to Art and Literature by reviving the dead Bataviasche Kunsten en Wetenschappen institution

The failure in the political field made Raffles have to turn and change direction not to think about politics but to turn to observers of culture, especially what is happening in Javanese society. Predicated as an oriental with Anglo-European characteristics, Raffles also still realizes that in terms of the inspiration for implementing politics starting from the thoughts of Dirk Van Hoegendorp, it seems that his loyalty to this inspiration is still continuing because Raffles also became an active member in the Bataviasch Genootschap voor Kunsten en Wetenschappen association while he was Ruling over this institution is none other than the pioneer of Dirk Van Hoegendorp who is considered his spiritual teacher.

Raffles was also aware of the ability to switch to orientalism ideology, who at that time still felt vague, only because while in power Raffles greatly contributed to the inspiration of various cultural issues in the archipelago thanks to his predecessor, an Englishman named Marsden who had been on the island of Sumatra and wrote His major work, History of Sumatra in 1784, is considered to give its own spirit about its cultural exploration. In addition, Raffles longed for his assistants, including John Crawfurd who was an expert on Eastern customs, Collin Mackenzie who was careful in collecting Javanese cultural artifacts, and Thomas Horfsfield was someone who helped in various types of botany found around the Dutch East Indies.

It's possible to defend privacy if you get ridiculed with the predicate of failing in terms of governance, but by starting to write the book "The History of Java" you don't feel like a failure in terms of cultural development or empowerment. Therefore, although he was reluctant to leave the island of Java and while also serving in Bengkulu, it seems that Raffles still loves Javanese culture. This was revealed when Raffles informed the Governor-General Lord Minto that despite his success in Singapore, he also always informed the British center. It has even held an exhibition about Javanese culture which is considered very important for the British. Is this what underlies that Raffles by establishing a museum as a representative icon that he is a true orientalist.

\section{References}

1. Alatas, Syed H. (1971), Thomas Stamford Raffles, Schemer or Reformer?,Sydney: Angus and Robertson.

2. Archer, Mildred en John S. Bastin (1978), The Raffles Drawings in the India Office Library London. Kuala Lumpur: Oxford University Press.

3. Barley, Nigel, red. (1999), The Golden Sword, Stamford Raffles and the East. Londen: British Museum Press

4. Barley, Nigel (2009), In the Footsteps of Stamford Raffles . Singapore: Monsoon Books.

5. Bastin, John and Bea Brommer (1979), Nineteenth Century Prints and Illustrated Books of Indonesia. Antwerp: Het Spectrum Utrecht

6. Bastin, John S. (1954). The Development of Raffles' Ideas on the Land Rent System in Java and the Mackenzie Land Tenure Commission ('s Gravenhage: Nijhoff). 
Iswahyudi et./al Raffles's observations of the arts of visual culture in Java during his reign in 1811-1816

7. Bastin, John S. (1957). The Native Policies of Sir Stamford Raffles in Java and Sumatra: an Economic Interpretation (Oxford: At the Clarendon Press).

8. Bastin, John S. (1999). "Preface", in The Life of Sir Stamford Raffles Demetrius C. Boulger, (Amsterdam: The Pepin Press).

9. Bastin, John S. (2004). Sir Stamford Raffles's The History of Java, a Bibliographical Essay (Eastbourne: A. Rowe).

10. Bohrer, Frederick (2003), Orientalism and Visual Culture. Cambridge: Cambridge University Press

11. Boulger, Demetrius C. (1999). The Life of Sir Stamford Raffles.Amsterdam: The Pepin Press: 1 uitgave 1897.

12. Burgers, Herman (2011) De Garoeda en de Ooeivaart: Indonesie van kolonie tot nationale staat. KITLV Uitgeverij, Leiden

13. Carey, Peter red. (1992). The British in Java 1811-1816, A Javanese Account, (Oxford: Oxford University Press).

14. Cohen, Matthew I. "British Performances of Java 1811-1822”, South East Asia Research 17, 1: 87 109.

15. Drieënhuizen, C.A. (2011). "De kunst van het verzamelen, koloniale verzamelaars en de VVAK", Aziatische Kunst 41e jaargang, Nr. 3: 2-15.

16. Fagg, William (1970), The Raffles Gamelan: A Historical Note, London: British Museum

17. Furnivall, J.S. (1939). Netherlands India, A Study of Plural Economy (Cambridge: University Press).

18. Gallop, Annabel T. (1995). Early Views of Indonesia, Drawings from the British Library (Londen: The British Library).

19. Gardner, Brian (1972), The East India Company. New York: The McCall Publishing Co.

20. Glamann, Kristoff. European Trade 1500-1750. London: Fontana, 1981.

21. Glendinning, Victoria (2012). Raffles and the Golden Opportunity (Londen: Profile Books).

22. Groeneman, J. 1890. De Gamelan te Jogjakarta, dengan pengantar "Over Onze Kennis der Javansche Miziek", oleh J.P.N, Land. Amsterdam: Johannes Muller

23. Groot, Hans (2009). Van Batavia naar Weltevreden. Het Bataviaasch Genootschap van Kunsten en Wetenschappen 1778-1867 (Leiden: KITLV).

24. Haan, F. de (1901). "De historie van een oudgast", Tijdschrift voor Indische Taal-, Land- en Volkenkunde Deel XLIII: 195-225.

25. Hobsbawm, Eric (2003), The Invention of Tradition. New York: Cambridge University Press

26. Holt, Claire. 2000. Art in Indonesia, terjemahan R.M. Soedarsono, Melacak Jejak Perkembangan Seni Di Indonesia. Bandung: MSPI

27. Knaap, Gerrit J. et al. (2007). Grote Atlas van de Verenigde Oost-Indische Compagnie, deel 2 Java en Madoera (Voorburg: Asia Maior/Atlas Maior).

28. Krom N.J. (1920). "Engelhard over de Javaansche Oudheden", Bijdragen tot de Taal-, Land-en Volkenkunde van Nederlandsch Indië juli: 435-48.

29. Mault, Natalie A. (2005), Java as a Western construct: an examination of Sir Thomas Stamford Raffles "The History of Java". A Thesis Submitted to the Graduate Faculty of the Louisiana State University and Agricultural and Mechanical College, The School of Art, 2005

30. Noltie, Henry J. (2009). Raffles' Ark redrawn, Natural History Drawings from the Collection of Sir Thomas Stamford Raffles (Londen: British Library).

31. Norman, H.D. Levyssohn (1857), De Britsche heerschappij over Java en onderhoorigheden (18111816). 's Gravenhage: Belinfante

32. Onghokham (1991). "Daendels en de vorming van het koloniale en modern Indonesië", in F. van Anrooy et al. reds. ,Herman Willem Daendels, 1762-1818: Geldersman, patriot, Jacobijn, Generaal, hereboer, maarschalk, Gouverneur. Van Hattem naar St. George del Mina (Utrecht: Matrijs, cop.).

33. Peltre, Christine (1998), Orientalism in Art. New York: Abbeville 
34. Quigley, Sam (1996), “The Raffles Gamelan at Claydon House.” Journal of the American Musical Instrument Society, Vol. 22, p. 5-41

35. Raffles, Sophia (1992), Memoir of the Life and Public Services of Sir Thomas Stamford Raffles. Singapore: Oxford University Press

36. Raffles, Thomas Stamford (1965), The History of Java. New York: Oxford University Press

37. Ricklefs M.C. (1993). A History of Modern Indonesia since c. 1300 (Hampshire: The Macmillan Press LTD.).

38. Said, Edward W. (1978). Orientalism. New York: Vintage Books

39. Spierings, Astrid (2013), Winnaar en Verliezer, De reputaties van Thomas Stamford Raffles en Nicolaus Engelhard naast elkaar gezet. Scriptie ter verkrijging van de graad van Master of Arts in History aan de Universiteit Leiden. Afstudeerrichting: Colonial and Global History

40. Taylor, Jean G. (1988). Smeltkroes Batavia, Europeanen en Euraziaten in de Nederlandse vestigingen in Azië (Groningen: Wolters-Noordhoff).

41. Tiffin, Sarah (2008). "Raffles and the Barometer of Civilisation: Images and Descriptions of Ruined Candis", The History of Java, Journal of the Royal Asiatic Society, Series 3, 18, 3: 341-60.

42. Wall, Victor I. van der (1930). The Influence of Olivia Mariamne Raffles on European Society in Java (1812 - 1814) (Batavia: s.n.).

43. Weatherbee, D.E. (1978). "Raffles' Sources for Traditional Javanese Historiography and the Mackenzie Collections", Indonesia Vol. 26: 63-93.

44. Van Niel, R. (2005), Java's Northeast Coast 1740-1840, A Study in Colonial Encroachment and Dominance. Leiden: CNWS Publications, 2005 